\title{
BCL2 Gene
}

National Cancer Institute

\section{Source}

National Cancer Institute. BCL2 Gene. NCI Thesaurus. Code C17963.

This gene is involved in apoptotic regulation. Overexpression of this gene promotes the pathogenesis of B-Cell lymphomas, due to anti-apoptotic activity. 